\title{
Scrutinising the secret state: parliamentary oversight of the intelligence and security agencies
}

\author{
Hugh Bochel, Andrew Defty and Andrew Dunn \\ University of Lincoln
}

In the wake of 9/11, the war in Iraq and terrorist attacks in London and Glasgow, the activities of the intelligence and security agencies (MI5, MI6 and GCHQ) and the way in which intelligence is handled by governments have become issues of widespread concern and importance. Yet, until relatively recently intelligence and security matters have not been subject to parliamentary scrutiny or debate. From the 1980s the veil of secrecy which had surrounded the intelligence and security agencies has gradually been lifted, with legislation, including the Security Service Act 1989 and the Intelligence Services Act 1994, placing the agencies and their activities on a statutory footing. This legislation also created, for the first time, some form of oversight of the agencies, with the establishment of commissioners to monitor the issuing of warrants to interfere with property and communications, and the creation of a committee of parliamentarians, the Intelligence and Security Committee (ISC), to examine the 'administration, policy and expenditure' of the intelligence and security agencies.

However, whilst parliament's contribution to the oversight of the intelligence and security agencies is central to providing them with democratic legitimacy and accountability (Cabinet Office, 2002), and its role in the scrutiny of legislation and policy relating to the use of intelligence is growing, the current system raises a number of questions including around the effectiveness of the ISC, the broader role of parliament and parliamentarians, and their ability to scrutinise the agencies and the government's use of intelligence.

\section{The Intelligence and Security Committee}

The establishment of the ISC was a significant step in the development of parliamentary oversight of the British intelligence and security agencies. It operates within the 'ring of secrecy' and has therefore for the first time allowed MPs and Peers to have wide-ranging access to the intelligence and security agencies, documents and staff. The ISC sets its own agenda and, although its proceedings remain secret, it publishes annual reports, and has also produced a number of additional reports on subjects of its own choosing. Although its mandate is limited to the examination of the 'administration, policy and expenditure' of the intelligence and security agencies, the Committee has shown an increasing propensity to consider operational matters, and some recent studies have argued that it has exceeded expectations in terms of access to information and established itself as a serious critic of the agencies, for example, with reports on the handling of detainees by British intelligence personnel in Afghanistan, Guantanamo Bay and Iraq (Gill and Phythian, 2006; Glees, Davies and Morrison, 2006; Phythian 2007).

However, the ISC does not provide parliamentary oversight as it is generally understood with regard to other policy areas. Indeed, it is something of a constitutional anomaly, being a committee of parliamentarians, but not a committee of parliament. Unlike select committees the ISC is a statutory committee, the members of which are appointed by the Prime Minister after consultation with opposition 
leaders. It meets in secret within the Cabinet Office and is staffed by Cabinet Office officials rather than parliamentary clerks. It has no power to require the agencies to provide information, and it reports directly to the Prime Minister, who is able to censor its reports before they are laid before parliament. The Committee's anomalous status has led a number of observers to argue that it does little to make the intelligence and security agencies more accountable, noting in particular that the separation of the Committee from parliament, and its real and symbolic proximity to the executive and the agencies it is designed to scrutinise, has compromised its independence (Lustgarten and Leigh, 1994; Weir and Beetham, 1999; Gill 2007). Some have argued that the Prime Minister's broad powers to censor reports before publication could be used to prevent the disclosure of matters that involve some abuse of functions or scandals (Wadham, 1994). Questions have also been raised about the ISC's reliance on the agencies to supply information in response to requests from the Committee, and the role of ministers acting as 'gatekeepers' in the provision of that information (Wadham, 1994; Gill, 1996). These concerns have been reinforced by reports from the ISC itself about a lack of candour on the part of Ministers (ISC, 2003), and prominent recent cases in which the Committee has revisited earlier enquiries to take account of material which was not made available to them at the time of their original investigations (ISC, 2009a, 2009b).

Perceived weaknesses in the structure and work of the ISC have been used to reinforce calls for its replacement with a parliamentary select committee (for example, Phythian, 2007). Although proposals for a select committee on intelligence predate the creation of the ISC, recent statements on both sides of the House suggest that the issue has risen up the political agenda. Proposals for changes to the handling of intelligence by government and the oversight of intelligence by parliament have been made in statements by the Conservative Shadow Secretary of State for Home Affairs, and in the Conservative Party's national security green paper (Conservative Party, 2009), whilst the Government's proposals for constitutional reform have conceded that because the ISC's reports, 'are prepared under separate arrangements and the Committee meets only in private, some argue that the process is insufficiently transparent', and as a result proposed a number of changes to the way in which the ISC operates, including public hearings, greater transparency in appointments, and reviewing the way in which the committee works with parliamentary select committees (Ministry of Justice, 2007).

\section{The wider role of parliament}

The Government's proposals for reform of the ISC may be seen as a response to a growth in parliamentary interest in the work of the intelligence and security agencies and in the Government's use of intelligence. One consequence of the existence of the ISC has been an increase in the number of parliamentarians with in-depth knowledge of the work of the agencies. It has also increased the number of opportunities for parliamentarians to debate intelligence issues, with ISC reports having been the subject of an annual debate in the House of Commons since 1998, and in the House of Lords from 2009.

The ISC may also be seen to have stimulated parliamentary interest in others ways. A number of parliamentary select committees have sought to carry out their own investigations in areas already scrutinised by the ISC, with the Foreign Affairs 
Committee's investigation into the government's presentation of the case for war in Iraq (FAC, 2004) and the Joint Committee on Human Rights investigation into allegations that UK intelligence personnel were complicit in torture (JCHR, 2009) both highlighting perceived limitations in the work of the ISC. Indeed, the government's own decision to appoint an independent committee chaired by Lord Butler to examine intelligence on Iraqi weapons of mass destruction was seen by some as a tacit acceptance that the ISC lacks legitimacy (Leigh, 2005). Similarly, the Home Affairs Committee (1999), the Foreign Affairs Committee (2004), and the Joint Committee on Human Rights (2006) have all called for greater accountability and parliamentary oversight of the intelligence and security agencies, including the replacement of the ISC with a parliamentary select committee. There is also some evidence of growing interest in House of Lords in the scrutiny of intelligence issues, including in 2009 its first ever debate on the work of the Intelligence and Security Committee. The House of Lords also contains a significant body of expertise on intelligence, with eleven former members of the ISC now sitting in the House of Lords, along with former Government ministers and individuals from senior ranks in the armed forces, who have direct experience of handling intelligence material. Recent appointments have also brought into the House Peers with direct experience of the agencies, most notably Pauline Neville-Jones, former Chair of the Joint Intelligence Committee, and Eliza Manningham-Buller, the former Director General of MI5.

However, whilst there is evidence of some growth in parliamentary interest in intelligence it is not clear whether parliament has the capacity to provide effective oversight of the intelligence and security agencies. A number of scholars have observed that with few votes or debates, and consequently little opportunity for personal recognition or political advantage, there is little incentive for parliamentarians to take an interest in matters relating to intelligence. Perhaps as a result of this, some have identified a lack of expertise among parliamentarians on intelligence issues (Lustgarten and Leigh, 1994; Robertson, 1998; Defty 2008). This may have an impact upon the work of the ISC, as access to information is in part dependent on the ability to know which questions to ask. As parliamentarians make up the Government, it may also have an impact on the effective use of intelligence in policymaking, as observed by the Butler inquiry (Butler, 2004).

\section{Conclusions}

Despite recent developments, Parliament's capacity to provide effective oversight of the intelligence and security issues is not clear. Whilst the establishment and development of the ISC has been a significant change, a number of observers in parliament and beyond have identified limitations to the Committee's ability to provide effective scrutiny.

However, the focus on the role and nature of the ISC arguably serves to confuse debates over the extent to which parliament is able to scrutinise intelligence issues. Whilst changes to the Committee may improve its ability to provide oversight of the agencies, it is parliament as a whole which is required to scrutinise the Government's use of intelligence, as for example, in making the case for war in Iraq. In recent years a number of bodies have brought forward recommendations for strengthening parliament, including the Hansard Society's Commission on Parliamentary Scrutiny 
(2001), the Conservative Party's Commission to Strengthen Parliament (2000), the House of Commons Modernisation Committee (2002). If future governments are likely to want to continue to use intelligence to garner public and parliamentary support for policy, and given the importance of parliament in providing legitimacy to the work of the intelligence and security agencies, it is perhaps important that debates about parliament's ability and role in scrutinising them and their work, should be discussed more widely and linked more closely to other proposals for parliamentary reform.

\section{References}

Butler, Lord (2004) Review of Intelligence on Weapons of Mass Destruction, London: The Stationery Office.

Cabinet Office (2002) Intelligence Oversight, London: The Stationery Office.

Commission to Strengthen Parliament (2000) Strengthening Parliament, London:

Conservative Party.

Conservative Party (2009) A Resilient Nation: National Security Green Paper,

London: Conservative Party.

Defty, A. (2008) 'Educating Parliamentarians about Intelligence: The role of the British Intelligence and Security Committee', Parliamentary Affairs, vol 61, no 4: 621-41.

Foreign Affairs Committee (2004) Implications for the Work of the House and its Committees of the Government's Lack of Co-operation with the Foreign Affairs Committee's Inquiry into The Decision to go to War in Iraq, London: The Stationery Office.

Gill, P. (1996) 'Reasserting Control: Recent Changes in the Oversight of the UK Intelligence Community', Intelligence and National Security, vol 11, no 2: 313-31. Gill, P. (2007), 'Evaluating Intelligence Oversight Committees: The UK Intelligence and Security Committee and the "War on Terror" Intelligence and National Security, vol 22, no 1: 214-37.

Gill, P. and Phythian, M. (2006) Intelligence in an Insecure World, Cambridge: Polity Press.

Glees, A., Davies, P. H. J. and Morrison, J. N. L. (2006) The Open Side of Secrecy: Britain's Intelligence and Security Committee, London: Social Affairs Unit. Hansard Society Commission on Parliamentary Scrutiny (2001) The Challenge for Parliament: Making Government Accountable, London: Vacher Dod.

Home Affairs Committee (1999) Accountability of the Security Service, London: The Stationery Office.

Intelligence and Security Committee (2003) Iraqi Weapons of Mass Destruction: Intelligence and Assessments, London: The Stationery Office.

Intelligence and Security Committee (2009a) Could 7/7 have been prevented? Review of the intelligence on the London terrorist attacks on 7 July 2005, London: The Stationery Office.

Intelligence and Security Committee (2009b) Alleged complicity of the UK intelligence and security Agencies in torture or cruel, inhuman or degrading treatment, press release, 17 March, http://www.cabinetoffice.gov.uk/media/143156/090317_alledged.pdf, accessed $15 / 02 / 10$. 
Joint Committee on Human Rights (2006) Counter-Terrorism Policy and Human Rights: Prosecution and Pre-Charge Detention, London: The Stationery Office. Joint Committee on Human Rights (2009), Allegations of UK complicity in torture, London: The Stationery Office.

Leigh, I. (2005), 'The UK's Intelligence and Security Committee' in Born, H. and Caparini, M. (eds), Democratic Control of Intelligence Services: Containing Rogue Elephants, Aldershot: Ashgate, 177-94.

Lustgarten, L. and Leigh, I. (1994) In From the Cold: National Security and Parliamentary Democracy, Oxford: Oxford University Press.

Ministry of Justice (2007) The Governance of Britain, London: The Stationery Office. Modernisation Committee (2002) Modernisation of the House of Commons: A Reform Programme, London: The Stationery Office.

Phythian, M. (2007), 'The British Experience with Intelligence Accountability', Intelligence and National Security, vol 22, no 1: 75-99.

Robertson, K.G. (1998), 'Recent Reform of Intelligence in the United Kingdom:' Intelligence and National Security, 13, 2: 144-158.

Wadham, J. (1994) 'The Intelligence Services Act 1994', Modern Law Review, vol 57, no 6: 916-27.

Weir, S. and Beetham, D. (1999) Political Power and Democratic Control in Britain: The Democratic Audit of the United Kingdom, London: Routledge. 